ISSN 0258-7122

Bangladesh J. Agril. Res. 39(3): 471-477, September 2014

\title{
DETERMINATION OF FERTILIZER DOSE FOR MAIZE IN POTATO- MAIZE-T. AMAN RICE CROPPING PATTERN
}

\author{
M. J. U. SARKER ${ }^{1}$, M. ALI ${ }^{2}$, A. K. CHOUDHURY ${ }^{3}$ \\ M. Z. H. PRODHAN ${ }^{4}$ AND MST. A. AKHTER ${ }^{5}$
}

\begin{abstract}
A field experiment was conducted at the Multilocation Testing Site (MLT) Sherpur, Bogra (AEZ 4) during November 2007-08 to October 2008-09 to find out a suitable fertilizer dose for maize as a succeeding crop following potato under Potato-Maize- T.Aman rice cropping pattern. The treatments were, $\mathrm{T}_{1}$ : Soil test based (STB) fertilizer dose of NPKS following FRG, 2005, $\mathrm{T}_{2}$ : STB of $75 \%$ recommended dose of $\mathrm{PKS}+$ full $\mathrm{N}, \mathrm{T}_{3}$ : $\mathrm{STB}$ of $50 \%$ recommended dose of PKS + full $\mathrm{N}_{\text {and }} \mathrm{T}_{4}$ : Farmers practice. From the two years' results, it was found that the most profitable grain yield of maize (7.54 t/ha) was obtained from the treatment $\mathrm{T}_{2}$ and the lowest $(6.16 \mathrm{t} / \mathrm{ha})$ was in $\mathrm{T}_{4}$ (Farmer's practice). Economic analysis showed that the treatment $\mathrm{T}_{2}$ gave the highest net return, benefit cost ratio was also higher in maize. Fertilizer dose could be reduced by $25 \%$ for N. Considering all the issues, maize was best fitted crop under PotatoMaize-T. Aman cropping sequence in AEZ 4 at MLT site Sherpur, Bogra.
\end{abstract}

\section{Introduction}

Soil fertility is one of the important dynamic properties of natural soil resources. There are many causes for degradation of soil fertility. Excess use of soil resources and adoption of inappropriate farming practices induce the soil degradation, such as soil erosion, nutrient mining and depletion of soil carbon accelerated soil acidification in Bangladesh (Chalk et al, 2002). The average organic matter in the soil is about $1 \%$ to $2 \%$ over the last 20 years due to intensive cultivation (Miah et al., 1993). The fertility status of most of the soil of Bangladesh is gradually deteriorating over the years (Ali et al., 1997). With the increase of cropping intensity, using of high yielding varieties, imbalance use of inorganic fertilizers and improper management practices leading to deplete soil fertility in the country. The use of chemical fertilizers as a supplemental source of nutrients has been increasing steadily in Bangladesh but most of the farmers usually do not apply it in balanced proportions (BARC, 1997). Again, some amounts of nutrients are left over in the soil which is being utilized by the succeeding crop. In this context, determination of proper fertilizer dose

${ }^{1}$ Chief Scientific Officer, ${ }^{2}$ Scientific Officer, ${ }^{3}$ Senior Scientific Officer, On-Farm Research Division, Bangladesh Agricultural Research Institute (BARI), Gazipur, ${ }^{4}$ Senior Scientific Officer, ${ }^{5}$ Scientific Officer, On-Farm Research Division, BARI, Bogra, Bangladesh. 
considering the residual effect of the nutrient is a very important factor for gaining desirable crop yield as well as sustainable production.

Potato-Maize-T.Aman rice is one of the promising cropping patterns in Bogra. Farmers of this area grow maize in residual nutrients of preceding potato crop and use lower dose of fertilizer. Both potato and maize in this cropping pattern is nutrient exhaustive crops. Further, nutrient requirement of these two crops is higher compared to many other field crops. Maize is a heavy feeder of nutrients, hence, it withdraws heavy dose of nutrients from soil for plant growth. To produce one ton of grain and dry matter, maize crop withdraws $20 \mathrm{~kg}$ of N, $3.5 \mathrm{~kg}$ of $\mathrm{P}_{2} \mathrm{O}_{5}, 20 \mathrm{~kg}$ of $\mathrm{K}_{2} \mathrm{O}$, and $4 \mathrm{~kg}$ of $\mathrm{S}$ from the soil (BARC, 2005). The pattern of withdrawal of nutrients grows up with the growth of crop over the time and reaches its peak during flowering of crop and after that it starts slowing down. It was observed that nutrient deficiency is common problem in maize that ultimately decreases the yield. Under such circumstances, better and efficient nutrient management system is a pre-requisite for maize production in this cropping pattern. There is no recommended dose for this pattern in BARC developed National Fertilizer Recommendation Guide' 2005. For sustainable higher yield and maintaining the fertility status of soil, it is needed to develop proper fertilizer dose for maize as a succeeding crop of potato. Considering the above facts, the trial is undertaken with the following objectives.

i. To find out the suitable fertilizer dose for maize as a succeeding crop of potato;

ii. To find out the economic dose of fertilizer for maize after cultivation of potato.

\section{Materials and Method}

The experiment was conducted at the MLT site, Sherpur, Bogra during 2007-09. Before conducting the experiment, soil samples were collected at a depth of 0-15 $\mathrm{cm}$ for laboratory analysis and the data of soil status is presented in Table 1 . The first crop of this pattern was potato variety Cardinal was used. The crop was planted during 30 November to 05 December with five dispersed replications. Fertilizer rates for potato were @ 164- 49-99-14- 2-1 kg NPKSZnB/ha (Farmers' practice). The source of NPKSZn, and B were Urea, Triple Super Phosphate, Muriate of Potash, Zinc Sulphate, and Borax. The full dose of TSP, MoP, Gypsum, Zinc sulphate, Borax, and half of urea were applied at the time of final land preparation. Remaining half of urea was side dressed at 30-35 days after sowing (DAS) at the time of earthing up followed by irrigation. Irrigation was provided after 15-20 and 30-35 DAS, fungicide was sprayed three times during the whole growth period. The crop was harvested from 15 to 20 February. In case of maize, Pacific 11 was used as the variety and the four fertilizer packages were 
$\mathrm{T}_{1:}$ Soil test based (STB) of NPKS following FRG, 2005, $\mathrm{T}_{2}$ : Soil test based full $\mathrm{N}+75 \%$ recommended dose of PKS, $\mathrm{T}_{3}$ : Soil test based full $\mathrm{N}+50 \%$ recommended dose of PKS and $\mathrm{T}_{4}$ : Farmers' practice. Fertilizer doses for farmers' practice was formulated by interviewing 40 different farmers of the site. The estimated fertilizer doses were $\mathrm{T}_{1}=196-37-93-25-1.94 \mathrm{~kg}$ NPKSZn $/ \mathrm{ha}, \mathrm{T}_{2}=$ 196-27-70-19-1.45 kg NPKSZn/ha, T $_{3}=196-18-47-13-0.97 \mathrm{~kg}$ NPKSZn $/ \mathrm{ha}$, and $\mathrm{T}_{4}=104-7-19-4-0 \mathrm{~kg} \mathrm{NPKSZn} / \mathrm{ha}$, respectively. Half of Urea and all TSP, MoP, Gypsum, and Zinc Sulphate were applied as broadcast prior to sowing. Remaining half of Urea was applied as side dress at 8-10-leaf stage followed by irrigation. Seeds were sown in $75 \mathrm{~cm} \times 20 \mathrm{~cm}$ spacing from 18 to 22 February and the crop was harvested from 10 to 15 June. The third crop of this pattern was $\mathrm{T}$. Aman rice variety BRRI dhan32. The fertilizer was used on T.Aman rice @ 9016-34-5 kg NPKS/ha, respectively. The full amount of TSP, MoP, and Gypsum were applied as broadcast and incorporated with soil during final land preparation. Urea was applied in three equal splits at 15 days after transplantation at tillering stage and 5-7 days before panicle initiation. Thirty to 35 days old seedlings were transplanted from 15 to 20 July. Two weedings were done at the time of 1 st and $2^{\text {nd }}$ top dress. The crop was harvested from 18 to 22 November. All the collected data were analyzed statistically and the mean separation was adjudged by Duncan's Multiple Range Test (Gomez and Gomez, 1984).

Table 1. Soil analysis values of different samples collected from MLT site Sherpur, Bogra.

\begin{tabular}{|c|c|c|c|c|c|c|c|c|c|c|}
\hline & \multicolumn{10}{|c|}{ Analytical results } \\
\hline & \multirow{2}{*}{$\mathrm{pH}$} & \multirow{2}{*}{$\begin{array}{l}\text { OM } \\
(\%)\end{array}$} & \multirow{2}{*}{$\begin{array}{l}\text { Total } \\
\text { N (\%) }\end{array}$} & \multicolumn{3}{|c|}{ (meq/100g soil) } & \multicolumn{4}{|c|}{ (mg/g soil) } \\
\hline & & & & $\mathrm{Ca}$ & $\mathrm{Mg}$ & $\mathrm{K}$ & $\mathrm{P}$ & $S$ & $\mathrm{Zn}$ & $\mathrm{B}$ \\
\hline $\begin{array}{l}\text { Value } \\
\text { obtained }\end{array}$ & 5.92 & 1.30 & 0.084 & 1.92 & 0.78 & 0.14 & 14.67 & 15.52 & 1.04 & 0.30 \\
\hline $\begin{array}{l}\text { Critical } \\
\text { level }\end{array}$ & - & - & 0.12 & 2.00 & 0.50 & 0.12 & 7.00 & 10.00 & 0.60 & 0.20 \\
\hline
\end{tabular}

\section{Results and Discussion}

In the first year 2007-08, a significant variation was observed among the treatments on the yield and yield contributing characters of maize except plant height and number of grains/cob (Table 2). The highest cob length $(18.32 \mathrm{~cm})$ was recorded with the treatment $T_{2}$ which was statistically similar to $T_{1}$ and $T_{3}$ and the lowest length $17.28 \mathrm{~cm}$ was found in $\mathrm{T}_{4}$ (Farmers' practice). The highest 1000 -grain weight ( $324 \mathrm{~g}$ ) was noted from the treatment $\mathrm{T}_{2}$ and was statistically superior with all other treatments. The highest grain yield $7.49 \mathrm{t} / \mathrm{ha}$ was obtained with the treatment $T_{2}$ which was statistically different from $T_{3}$ and $T_{4}$ but similar with $\mathrm{T}_{1}$. The lowest grain yield 6.40 t/ha was obtained with $\mathrm{T}_{4}$ (Farmers' practice). The highest stover yield was also recorded with the treatment $T_{2}$, which 
was statistically different from farmers' practice but similar with $T_{1}$ and $T_{3}$. No statistical difference was observed in case of plant height and number of grains/cob due to the different treatments. In the case of economic analysis, maize showed the highest gross return Tk. 97815/ha and net return Tk. 55415/ha from the treatment $\mathrm{T}_{2}$ but the farmers' practice $\left(\mathrm{T}_{4}\right)$ gave the highest benefit cost ratio 2.53 which was due to less fertilizer cost. The yield of potato, maize, and T.Aman rice are shown in Table 6. Similar findings were also reported by Yamada (1997) and Reuler and Janssen (1996).

Table 2. Yield and yield contributing characters of maize as succeeding crop following potato in a Potato-Maize-T.Aman rice cropping pattern at the MLT site, Sherpur, Bogra during the year of 2007-08.

\begin{tabular}{l|c|c|c|c|c|c}
\hline $\begin{array}{c}\text { Treatments (Fertilizer level } \\
\text { NPKSZn kg/ha) }\end{array}$ & $\begin{array}{c}\text { Plant } \\
\text { height } \\
(\mathrm{cm})\end{array}$ & $\begin{array}{c}\text { Length of } \\
\text { cob }(\mathrm{cm})\end{array}$ & $\begin{array}{c}\text { No. of } \\
\text { grains/ } \\
\mathrm{cob}\end{array}$ & $\begin{array}{c}1000- \\
\text { grain wt } \\
(\mathrm{g})\end{array}$ & $\begin{array}{c}\text { Grain } \\
\text { yield } \\
(\mathrm{t} / \mathrm{ha})\end{array}$ & $\begin{array}{c}\text { Stover } \\
\text { yield } \\
(\mathrm{t} / \mathrm{ha})\end{array}$ \\
\hline $\mathrm{T}_{1}(196-37-93-25-1.94)$ & $184 \mathrm{a}$ & $17.68 \mathrm{ab}$ & $487 \mathrm{a}$ & $320 \mathrm{~b}$ & $7.34 \mathrm{a}$ & $4.13 \mathrm{ab}$ \\
$\mathrm{T}_{2}(196-27-70-19-1.45)$ & $185 \mathrm{a}$ & $18.32 \mathrm{a}$ & $491 \mathrm{a}$ & $324 \mathrm{a}$ & $7.49 \mathrm{a}$ & $4.20 \mathrm{a}$ \\
$\mathrm{T}_{3}(196-18-47-13-0.97)$ & $181 \mathrm{a}$ & $17.64 \mathrm{ab}$ & $483 \mathrm{a}$ & $314 \mathrm{c}$ & $6.85 \mathrm{~b}$ & $3.86 \mathrm{ab}$ \\
$\mathrm{T}_{4}(104-7-19-4-0)$ & $178 \mathrm{a}$ & $17.28 \mathrm{~b}$ & $475 \mathrm{a}$ & $314 \mathrm{c}$ & $6.40 \mathrm{c}$ & $3.62 \mathrm{~b}$ \\
$($ Farmers' practice $)$ & 7.89 & 7.86 & 8.61 & 5.63 & 7.09 & 8.56 \\
\hline CV $(\%)$ & & & & & & \\
\hline
\end{tabular}

Table 3. Cost and return analysis for maize as succeeding crop following potato in a Potato-Maize-T.Aman rice cropping pattern at the MLT site Sherpur, Bogra during the year of 2007-08.

\begin{tabular}{c|c|c|c|c}
\hline Treatments & $\begin{array}{c}\text { Gross return } \\
\text { (Tk./ha) }\end{array}$ & $\begin{array}{c}\text { Cost of production } \\
\text { (Tk./ha) }\end{array}$ & $\begin{array}{c}\text { Net return } \\
\text { (Tk./ha) }\end{array}$ & BCR \\
\hline $\mathrm{T}_{1}$ & 95940 & 45847 & 50093 & 2.09 \\
$\mathrm{~T}_{2}$ & 97815 & 42340 & 55475 & 2.31 \\
$\mathrm{~T}_{3}$ & 89815 & 38425 & 50990 & 2.31 \\
$\mathrm{~T}_{4}$ & 84190 & 33342 & 50848 & 2.53 \\
\hline
\end{tabular}

Price $(\mathrm{Tk} / \mathrm{kg})$ : Seed $=160$, Urea $=6, \mathrm{TSP}=35, \mathrm{MoP}=35$, Gypsum $=6$, Zinc Sulphate $=$ 60 , Maize grain $=12.50$, Stover $=0.50$.

In the year 2008-09, significant effect of the imposed treatments were found on the yield and other yield contributing characters of maize except plant height, 1000-grain weight, and stover yield (Table 4). The highest length of cob (19.96 $\mathrm{cm}$ ) was recorded with the treatment $T_{1}$, which was statistically similar to that of $\mathrm{T}_{2}(19.24 \mathrm{~cm})$ and $\mathrm{T}_{3}(18.92 \mathrm{~cm})$ but differed significantly from $\mathrm{T}_{4}$ (Farmers' practice). Similar trend was also observed in the case of length of cob and no. of grains/cob. The highest grain yield (7.70 t/ha) was found in the treatment $T_{1}$ and 
it was statistically similar with $\mathrm{T}_{2}(7.59 \mathrm{t} / \mathrm{ha})$. The lowest grain yield (5.92 t/ha) was found in $\mathrm{T}_{4}$ (Farmers' practice), which was significantly different from other treatments. From Table 5, the cost and return analysis of maize showed that the highest gross return (Tk.100040/ha) was obtained with the treatment $\mathrm{T}_{1}$ which was closely followed by $T_{2}$ (Tk.98595/ha). The treatment $T_{2}$ gave the highest net return (Tk.47207/ha) followed by $\mathrm{T}_{1}$ (Tk.44658/ha), $\mathrm{T}_{3}$ (Tk.41672/ha) and $\mathrm{T}_{4}$ (Tk.36549/ha). But in case of benefit cost ratio, the highest value was obtained from the treatment $\mathrm{T}_{2}(1.92)$ followed by that of $\mathrm{T}_{3}$ and $\mathrm{T}_{4}$, and $\mathrm{T}_{1}$ gave the lowest (1.81). Similar findings were also reported by Killorn and Zourarakis (1992) and Alam (1995).

Table 4. Yield and yield contributing characters of maize as succeeding crop following potato in a Potato-Maize-T.Aman rice cropping pattern at the MLT site, Sherpur, Bogra during the year of 2008-09.

\begin{tabular}{l|c|c|c|c|c|c}
\hline $\begin{array}{l}\text { Treatments (Fertilizer } \\
\text { level NPKSZn kg/ha) }\end{array}$ & $\begin{array}{c}\text { Plant } \\
\text { height } \\
(\mathrm{cm})\end{array}$ & $\begin{array}{c}\text { Length of } \\
\text { cob }(\mathrm{cm})\end{array}$ & $\begin{array}{c}\text { No. of } \\
\text { grains/ } \\
\text { cob }\end{array}$ & $\begin{array}{c}1000- \\
\text { grain wt } \\
(\mathrm{g})\end{array}$ & $\begin{array}{c}\text { Grain } \\
\text { yield } \\
(\mathrm{t} / \mathrm{ha})\end{array}$ & $\begin{array}{c}\text { Stover } \\
\text { yield } \\
(\mathrm{t} / \mathrm{ha})\end{array}$ \\
\hline $\mathrm{T}_{1}(196-37-93-25-1.94)$ & $180 \mathrm{a}$ & $19.96 \mathrm{a}$ & $467 \mathrm{a}$ & $332 \mathrm{a}$ & $7.70 \mathrm{a}$ & $3.98 \mathrm{a}$ \\
$\mathrm{T}_{2}(196-27-70-19-1.45)$ & $179 \mathrm{a}$ & $19.24 \mathrm{ab}$ & $462 \mathrm{a}$ & $328 \mathrm{a}$ & $7.59 \mathrm{ab}$ & $3.84 \mathrm{a}$ \\
$\mathrm{T}_{3}(196-18-47-13-0.97)$ & $176 \mathrm{a}$ & $18.92 \mathrm{ab}$ & $455 \mathrm{a}$ & $328 \mathrm{a}$ & $6.83 \mathrm{~b}$ & $3.78 \mathrm{a}$ \\
$\mathrm{T}_{4}(104-7-19-4-0)$ & $171 \mathrm{a}$ & $18.82 \mathrm{~b}$ & $400 \mathrm{~b}$ & $326 \mathrm{a}$ & $5.92 \mathrm{c}$ & $3.75 \mathrm{a}$ \\
\hline $\mathrm{CV}(\%)$ & 7.07 & 6.79 & 5.21 & 6.74 & 8.05 & 8.08 \\
\hline
\end{tabular}

Table 5. Cost and return analysis for maize as succeeding crop following potato in a Potato-Maize-T.Aman rice cropping pattern at the MLT site, Sherpur, Bogra during the year of 2008-09.

\begin{tabular}{c|c|c|c|c}
\hline Treatments & $\begin{array}{c}\text { Gross return } \\
\text { (Tk./ha) }\end{array}$ & $\begin{array}{c}\text { Cost of production } \\
\text { (Tk./ha) }\end{array}$ & $\begin{array}{c}\text { Net return } \\
\text { (Tk./ha) }\end{array}$ & BCR \\
\hline $\mathrm{T}_{1}$ & 100040 & 55382 & 44658 & 1.81 \\
$\mathrm{~T}_{2}$ & 98595 & 51388 & 47207 & 1.92 \\
$\mathrm{~T}_{3}$ & 89065 & 47393 & 41672 & 1.88 \\
$\mathrm{~T}_{4}$ & 77675 & 41126 & 36549 & 1.88 \\
\hline
\end{tabular}

Price $(\mathrm{Tk} . / \mathrm{kg})$ : Seed $=190$, Urea $=12, \mathrm{TSP}=40, \mathrm{MoP}=40$, Gypsum $=6$, Zinc sulphate $=70$, Maize grain $=12.50$ and Stover $=0.50$

From the Table 6, it was found that the average of two years' yield of potato was $21.29 \mathrm{t} / \mathrm{ha}$, the average grain yield of maize and T.Aman were 7.54 and 3.91 $\mathrm{t} / \mathrm{ha}$, respectively. The average stover yield of maize was $4.02 \mathrm{t} / \mathrm{ha}$ and straw yield of rice was $4.54 \mathrm{t} / \mathrm{ha}$. 
Table 6. Yield of potato, maize and T. Aman in Potato-Maize-T. Aman rice cropping pattern at MLT site Sherpur during 2007-08 to 2008-09.

\begin{tabular}{|c|c|c|c|c|c|c|}
\hline \multirow[t]{2}{*}{ Name of crop } & \multicolumn{2}{|c|}{ Tuber/grain yield (t/ha) } & \multirow{2}{*}{$\begin{array}{c}\text { Average yield } \\
(\mathrm{t} / \mathrm{ha})\end{array}$} & \multicolumn{2}{|c|}{$\begin{array}{l}\text { Stover/straw } \\
\text { yield } \\
\text { (t/ha) }\end{array}$} & \multirow{2}{*}{$\begin{array}{c}\text { Average } \\
\text { yield } \\
\text { (t/ha) }\end{array}$} \\
\hline & $2007-08$ & 2008-09 & & $2007-08$ & $\begin{array}{c}2008- \\
09\end{array}$ & \\
\hline Potato & 20.45 & 22.12 & 21.29 & - & - & - \\
\hline Maize & 7.49 & 7.59 & 7.54 & 4.20 & 3.84 & 4.02 \\
\hline T.Aman rice & 3.85 & 3.97 & 3.91 & 4.38 & 4.70 & 4.54 \\
\hline
\end{tabular}

Table 7. Cost and return analysis of the whole cropping pattern (Potato-MaizeT.Aman rice) at the MLT site, Sherpur, Bogra (average of two years).

\begin{tabular}{l|c|c|c|c|c|c}
\hline Crop & $\begin{array}{c}\text { Average } \\
\text { tuber/grain yield } \\
\text { (t/ha) }\end{array}$ & $\begin{array}{c}\text { Stover/straw } \\
\text { yield } \\
\text { (t/ha) }\end{array}$ & $\begin{array}{c}\text { Gross } \\
\text { return } \\
\text { (Tk./ha) }\end{array}$ & $\begin{array}{c}\text { Cost of } \\
\text { production } \\
\text { (Tk./ha) }\end{array}$ & $\begin{array}{c}\text { Net } \\
\text { return } \\
\text { (Tk./ha) }\end{array}$ & BCR \\
\hline Potato & 21.29 & - & & & & \\
Maize & 7.54 & 4.02 & 334370 & 168500 & 165870 & 1.98 \\
T. Aman & 3.91 & 4.54 & & & & \\
\hline
\end{tabular}

Price $(\mathrm{Tk} . / \mathrm{kg})$ : Maize Seed $=175$, Rice seed $=20$, Potato seed $=15$, Maize grain $=12.50$ $\&$ Stover $=0.50$, Potato $=8$, Rice grain $=15$, Rice straw $=2$.

From the two years' studies, it was found that the treatment $T_{2}$ performed best. Maize cultivation was profitable after harvesting of potato in Potato-MaizeT.Aman cropping pattern. By adopting treatment $\mathrm{T}_{2}$ in maize cultivation, $\mathrm{PK}$ and $\mathrm{S}$ fertilizers can be saved by $25 \%$ of the recommended doses which led to achieve increase gross return of 334370 Tk./ha (Table 7). The cost of production for the whole cropping pattern was Tk. 168500/ha and the net return was Tk. 165870/ha. The benefit-cost ratio (BCR) was 1.98 signifying the superiority of the treatment $\mathrm{T}_{2}$.

\section{Conclusion}

From the above results, it could be concluded that the treatment $T_{2}$ was suitable for maize cultivationas a succeeding crop due to its higher net return and BCR. By adopting this practice, at least $25 \% \mathrm{P}, \mathrm{K}$, and $\mathrm{S}$ could be reduced in growing maize after potato under Potato-Maize-T.Aman rice cropping pattern. For maize cultivation under Potato-Maize-T.Aman rice cropping pattern in Sherpur areas, of Bogra district under AEZ-4, the fertilizer dose 196-27-70-19-1.45 NPKSZn $\mathrm{kg} / \mathrm{ha}$ can be recommended. 


\section{References}

Alam, M. N. 1995. Response of hybrid maize to tillage, nitrogen and moisture regimes after irrigated wetland rice. Ph.D. Thesis. in Crop Science. Faculty of the Inst. of Graduate Studies, Central Luzon State University, Munoz, Nueva Ecija, Philippines.

Ali, M. M, S. M. Shaheed and D. Kubota. 1997. Soil degradation during the period $1967-$ 1995 in Bangladesh. 11. Selected chemical characters. Soil Plant Nutr. 43: 870-890.

BARC (Bangladesh Agricultural Research Council). 1997. Fertilizer Recommendation Guide. Bangladesh Agril. Res. Council, Farmgate, New Airport Road, Dhaka, P. 25.

BARC (Bangladesh Agricultural Research Council). 2005. Fertilizer Recommendation Guide Bangladesh Agril. Res. Council, Farmgate, New Airport Road, Dhaka. P. 12.

Chalk, P. M., F. Zapta and G. Keerthisinghe. 2002. Towards integrated soil, water and nutrients management in cropping systems: The role of nuclear techniques. A FAO Study, Food and Agriculture Organizations in UnitedNations, Italy, Rome.

Gomez, K. A. and A. A. Gomez. 1984. Statistical Procedures for Agricultural Research. $2^{\text {nd }}$ edn., John Willey and Sons. New York, Pp. 680.

Killorn R. and D. Zourarakis. 1992. Nitrogen fertilizer management effects on corn grain yield and nitrogen uptake. J. Prod. Agric. 5: 142-148.

Miah, M. M. U., A. K. M. Habibullah and M. F. Ali. 1993. Depletion of organic matter in Bangladesh. In "Soil resilience and sustainable land use". Proceedings of International Symposium, held on 28 September to 2 October 1992, Budapest, Hungary, Pp. 70-79

Reuler H. V. and B. H. Janssen 1996. Optimum NPK management over extended cropping periods in South-West Cote d' Ivoire. Netherlands J. Agril. Sci. 44(4): 263277.

Yamada T. 1997. Nitrogen and potassium fertilizers for maize. Informacoes Agronomicas 78: $1-4$. 